\title{
PENGARUH PEMBELAJARAN DARING TERHADAP PRESTASI BELAJAR SISWA SD NEGERI PANNARA KOTA MAKASSAR
}

\author{
Elisabet Armin $\left.{ }^{1}\right)$, Muh. Khaedar $\left.{ }^{2}\right)$, Satriawati $\left.^{3}\right),\left(\right.$ Nuhadifah Amaliyah $\left.^{4}\right)$. \\ PGSD, Universiras Megarezky \\ elisabetarmin501@gmail.com, khaedarmuh@yahoo.co.id, satriawati@gmail.com, \\ nurhadifah.amaliyah05@gmail.com
}

\begin{abstract}
ABSTRAK
Elisabet Armin 2021. Pengaruh Pembelajaran Daring terhadap Prestasi Belajar Siswa SD Negeri Pannara Kota Makassar. Yang dibimbing oleh Muh. Khaedar dan Satriawati.

Penelitian ini bertujuan untuk mengetahui pengaruh pembelajaran daring terhadap prestasi belajar SD Negeri Pannara Kota Makassar. Jenis penelitian yang digunakan adalah Ex post facto dengan pendekatan kuantitatif. Populasi yang digunakan semua kelas IV, V, dan VI SD Negeri Pannara Kota Makassar yang terdiri dari 194 siswa. Sampel pada penelitian ini adalah siswa kelas VA yang terdiri dari 33 siswa. Instrumen penelitian yang digunakan adalah angket dan dokumentasi. Dengan teknik simple random sampling.

Hasil penelitian ini menggunakan statistik deskriptif, hasil pembelajran daring dengangan nilai rata-rata 32,58. Analisis prasyarat hasil uji normalitas pembelajaran daring 0,346 dan prestasi belajar 0,078 $>0,05$ (berdisribusi normal), hasil uji homogenitas 0,227 > 0,05 (homogen), hasil uji lineritas adalah 0,092> 0,05 dengan demikian terdapat linear pembelajaran daring terhadap prestasi belajar siswa. Analisis inferensial hasil uji hipotesis menunjukkan nilai sig 0,000 dengan kriteria Sig $(0,000)<\alpha(0,05)$. Kesimpulan dalam penelitian ini adalah terdapat pengaruh pembelajaran daring terhadap prestasi belajar siswa SD Negeri Pannara Kota Makassar.
\end{abstract}

Kata kunci : Pembelajaran Daring, dan Prestasi Belajar Siswa.

\section{ABSTRACT}

Elisabet Armn, 2021.The Effect of online Learning on student Achievement at Pannara Elementary School Makassar City. Supervisesed By MUH. Khaedar and Satriawati.

This study aimed was to determine the effect of online learning on learning achievement at SD Negeri Pannara Makassar City. The type of researtch used is Ex post facto with a quantitative apporoach. The population used all grades $I V, V$, and VI of SD Negeri Pannara Makassar City. Which consisted of 196 students. The sample in this study were students of class VA, which consisted of 33 students. The research instrument used a questionnaire and documentations with a simple random sampling technique. 
This study used descriptive statististed oon online learning outcomest with an overage value of 32.21 and learning achieventment of 32.58. Prerequisite analysis of online learning normaliti test results is 0.346 and learning achievement was $0.078>0.05$ (nomallity distributed), homogeneity tets results $0.227>0.05$ (homogeneous) linearity tets results are $0.092>0.05$;

This there was linear online learning on student achievement. Inverential analysis of the resuls of hypothesis testing showed the value of sig 0.000 whit the criteria of sig (0.000) < a (0.05). This study concludes that online learning affects student achievement in SD Negeri Pannara Makassar City.

Keywords: Online Learning and Student Learning achieevenment.

\section{PENDAHULUAN}

Pendidikan adalah Proses perubahan tingkah laku dan sikap seseorang atau sekelompok orang dalam usaha mendewasakan manusia melalui upaya pengajaran dan pelatihan (Yulmitasari 2020: 1). Bangsa Jerman melihat pendidikan sebagai Erziehung yang setara dengan educare, yakni : membangkitkan kekuatan terpendam atau pendidikan berarti pengolahan, mengolah, mengubah kejiwaan, mematangkan perasaan, pikiran, watak, mengubah kepribadiaan sang anak (Durotul Yatimah 2017: 1).

Pendidikan merupakan salah satu hal yang penting dalam kehidupan manusia. Pendidikan merupakan salah satu faktor untuk meningkatkan sumber daya manusia guna menciptakan penerus bangsa yang berkualitas serta mampu bersaing dengan Negara-Negara lain di dunia. Pemerintah Indnesia dengan programnya wajib belajar 12 tahun (UUD No 20 tentamg Sistem Pendidkan Nasional 2003). Merupakan suatu upaya untuk mencetak generasi penerus bangsa yang nantinya, bahkan sekarang pemerintah sudah memberikan fasilatas pendidikan gratis sampai jenjang sekolah menengah atas supaya seluruh penduduk Indonesia bisa mengeyam pendidkan. Upaya tersebut adalah dengan melakukan penyempurnaan kurikulum dari tahun ke tahun. Penyempurnaan tersebut dimulai dari kurikulum 1994 menjadi kurikulum berbasis kompetensi (KBK), kemudian kurikulum KBK disempurnakan lagi menjadi kurikulum tingkat satuan pendidikan (KTSP) dan kemudian disempurnakan lagi menjadi kurikulum 2013 yang berlaku hingga sekarang. Dengan disempurnakanya kurikulum tersebut diharapkan pendidikan dapat tercapai secara optimal berkaitan dengan perubahan kurukulum tersebut, guru sangat memiliki peran dalam mengololah proses pembelajaran didalam kelas.

(Jusmawati et al., 2021) Masa depan yang kian memiliki implikasi luas dan mendalam terhadap berbagai rancangan pengajaran dan teknik pembelajaran. Pada gilirannya para guru akan menyadari bahwa model maupun strategi pembelajaran yang konvensional tidak akan cukup membantu siswa.

Indonesia saat ini tengah dihadapkan dengan tantangan ditengah pandemi Covid-19, di mana pemerintah menghimbauh untuk masyarakat Indonesia ini di rumah saja. Pandemi Covid-19 ini tidak hanya mempengaruhi sektor ekonomi dan sosial, melainkan juga sektor pendidikan yang kini mau tidak mau harus mulai 
beradaptasi dengan era ini. Sehingga kegiatan pembelajaran yang semula dilakukan secara tatap muka beralih menjadi pembelajaran non tatap muka. Program tersebut dikenal dengan pembelajaran daring atau sistem E-learning atau online learning.

Pembelajaran daring merupakan pemanfaatan jaringan internet dalam proses pembelajaran (Isman, 2016: 587). Istilah yang digunakan adalah dalam jaringan dapat disingkat dengan daring. Pengunaan kata tersebut merupakan kata ganti online menjadi daring yang artinya adalah komonikasi maupun pertemuan yang dilakukan dengan mengunakan jaringan internet. Penyampain materi pembelajaran sudah beragam salah satunya adalah penyampaian pembelajaran melalui daring, pembelajaran yang menarik serta mudah diterima oleh siswa menjadi salah satu hal yang penting untuk menentukan prestasi siswa. prestasi dapat diartikan sebagai hasil yang diperoleh karena adanya aktivitas belajar yang telah dilakukan.

Berdasarkan hasil obeservasi di SD Negeri Pannara tanggal 9 November 2020 dengan adanya virus Covid 19 pembelajaran kini dilakukan melalui via whatsApp dengan menggunkan whatsApp, diharapkan dapat membantu proses pembelajaran siswa seseuai dengan tujuan yang diharapkan, dengan penerapan pembelajaran daring ini merupakan suatu hal yang baru yang yang pastinya akan berdampak pada prestasi belajar siswa. Berdasarkan latar belakang masalah diatas maka, peneliti tertarik untuk melakukan peneltiaan tentang "pengaruh pembelajaran daring terhadap Prestasi Belajar Siswa SD Negeri Pannara Kota Makassar"

\section{METODE PENELITIAAN}

Penelitian ini merupakan jenis penelitian ex post facto. Bentuk penelitian ini dipilih karena variabel-variabel bebasnya tidak dikendalikan, dalam arti variabel tersebut sudah terjadi. Jenis penelitian ex post facto menggunakan metode penelitian kuantitatif. Metode penelitian kuantitatif dapat diartikan sebagai metode penelitian yang berlandaskan pada filsafat positivisme, digunakan untuk meneliti pada populasi atau sampel tertentu, pengumpulan data menggunakan instrumen penelitian, analisis data bersifat statistik, dengan tujuan untuk

menguji hipotesis yang telah diterapkan (Sugiyono 2016: 16). Dalam penelitian ini peneliti mencari ada atau tidak ada pengaruh pembelajaran daring terhadap prestasi belajar siswa SD Negeri Pannara Kota Makassar.

\section{Analisis Deskrptif}

Analisis deskriptif merupakan analisis yang menggambarkan suatu data yang akan dibuat baik sendiri maupun secara kelompok. Tujuan analisis deskriptif untuk membuat gambaran secara sistematis dan akurat mengenai fakta-fakta serta hubungan antar fenomena yang diteliti (Arikunto 2010: 132).

\section{Analisis Iferensial}

Analisis statistik inferensial mengunakan teknik regresi sederhana untuk mengetahui ada atau tidak pengaruh pembelajaran daring terhadap prestasi belajar siswa SD Negeri Pannara Kota Makassar. Analisis tersebut mengunakan software 
SPSS 21.0 for windows dengan kriteria pengujian yang digunakan adalah signifikan $\geq \alpha$ dengan taraf $\alpha=0,05$. Pengujian hipotesis secara inferensial sebelum dilakukan maka terlebih dahulu akan dilakukan uji Prasyarat statistik prametik yang meliuti:

a. Uji Normalitas

Uji normalitas digunakan untuk mengetahui distribusi data, apakah berbentuk distibusi normal atau tidak untuk melakukan uji normalitas dIgunakan rumus kolmogorov-smirnov, jika nilai symp signifikan $\geq$ $\alpha=0,05$ maka data berdistribusi normal, jika Asymp signifikan $\leq \alpha=0,05$ maka distribusi data tidak normal.

b. Uji Homogenitas

Uji homogenitas bertujuan untuk apakah objek yang diteliti mempunyai varian yang sama. Bilah objek yang tidak mempunyai varian yang sama, maka uji anova tidak dapat diberlakukan metode yang digunakan dalam uji homogenitas, ini adalah metode varian terbesar dibandingkan dengan varian terkecil

c. Uji Lineritas

Uji lenearitas digunakan dengan tujuan untuk mengetahui apakah dua variabel yang akan dianalisis menunjukkan hubungan lancar atau tidak secara signifikan dengan bantuan software SPSS 21 .0 for windows dengan kriteria pengujian yang digunakan adalah signifikan $\geq \alpha$ dengan taraf $=0,05$, Perhitungan linearitas regresi sederhana menggunakan persamaan.

Keterangan:

$\mathrm{Y}=\mathrm{a}+\mathrm{b} \cdot \mathrm{X}$

Y : Variabel akibat

$\mathrm{X}$ : Variabet penyebab

a : Konstanta (nilai tetap)

b : koefisien Regresi

Uji hipotesis yang dilakukan pada penelitian ini digunakan uji-f nilai dengan melihat standardized coefficient beta.

$\mathrm{H}_{0}=$ Tidak ada pengaruh pembelajaran daring terhadap prestsi belajar siswa SD Negeri Pannara Kota Makassar

$\mathrm{H}_{1}=$ Ada pengaruh pembelajaran daring terhadap prestsi belajar siswa SD Negeri Pannara Kota Makassar

\section{HASIL DAN PEMBAHASAN}

\section{Analisis Deskriptif}

\section{a. Gambaran Pembelajaran Daring}

Pengolahan data dalam penelitian ini mengunakan analisis deskriptif yang menggambarkan suatu data yang akan dibuat baik dibuat sendiri maupun secara kelompok. Pengumpulan data menggunakan angket pembelajran daring yang dibagikan kepada 33 siswa kelas VA SD Negeri Pannara Kota Makassar. 
Berdasarkan kriteria pengkategorian angket yang diolah di SPSS 21 for windows maka diperoleh distribusi frekuensi angket pembelajaran daring pada tabel berikut:

\begin{tabular}{cc} 
Tabel Analisis Deskriptif Hasil Angket Pembelajaran Daring \\
\hline Statistik & Hasil Angket Pembelajaran Daring \\
\hline Ukuran sampel & 33 \\
Mean(rata-rata) & 32,21 \\
Median & 32,52 \\
Mode & 33 \\
Std Devation & 2,399 \\
Variance & 4,235 \\
Range & 8 \\
Minimum & 30 \\
Maksimum & 39 \\
\hline Jumlah & 216,743 \\
\hline
\end{tabular}

Berdasarkan tabel diatas menunjukkan bahwa pada hasil pengaruh pembelajaran daring SD Negeri Pannara Kota Makassar dengan nilai rata-rata 32,52 nilai terendah yaitu 30,00 dan nilai tertinggi 39,00 dengan standar devition 2,399 .

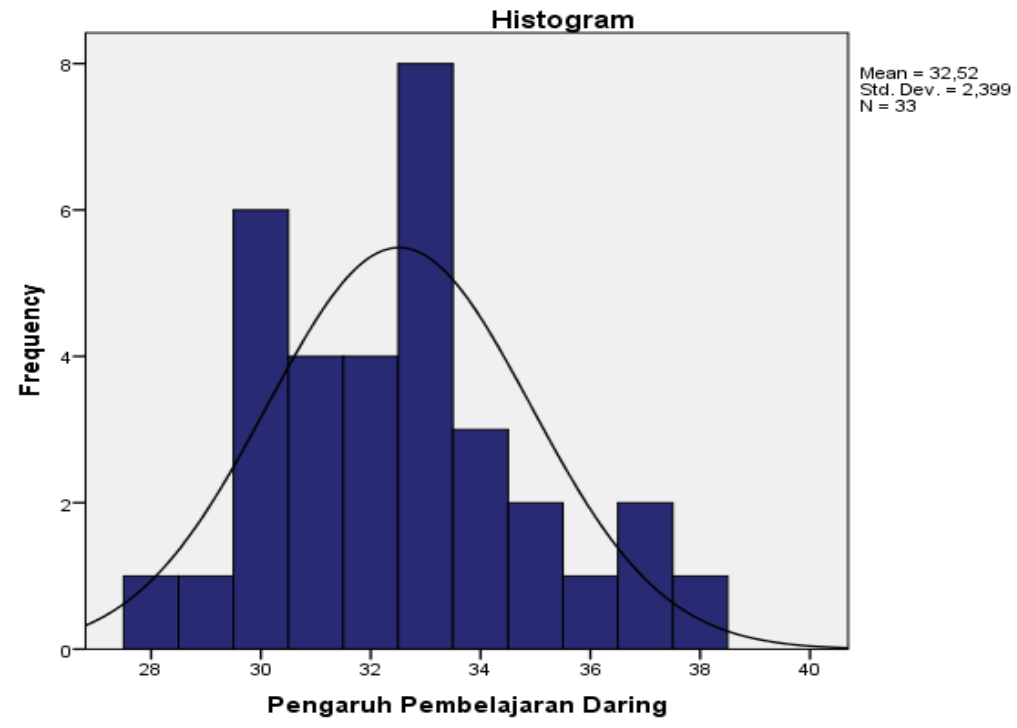

Berdasarkan data diatas menunjukkan bahwa pada hasil angket pembelajaran daring di SD Negeri Pannara Kota Makassar dengan nilai terendah yaitu 30,00, niali tertinggi 39,00 dan nilai rata-rata 32, 52 dengan std devation 2,399 .

b. Gambaran Prestasi Belajar

Pengelolaan data yang digunakan data dalam penelitiaan ini mengunakan analisis deskriptif yang menggambarkan suatu data yang akan dibuat baik dibuat sendiri maupun secara kelompok. Tujuan analisis deskriptif untuk membuat gambaran secara sistematis dan akurat. Pengumpulan data dilakukan dengan menggunkan angket prestasi belajar siswa yang dibagikan kepada 33 siswa kelas VA SD Negeri Pannara Kota Makassar. 
Berdasarkan kriteria pengkategorian, maka diperoleh distribusi frekuensi angket prestasi belajar pada tabel berikut:

Tabel Analisis Deskriptif Prestasi Belajar Siswa

\begin{tabular}{cc}
\hline Statistik & Prestasi belajar siswa \\
Ukuran sampel & 33 \\
Meann (rata-rata) & 32,58 \\
Median & 33,00 \\
Mode & 33 \\
Std devation & 2,255 \\
Variance & 2,877 \\
Range & 8 \\
Minimum & 31 \\
Maksimum & 39 \\
\hline Jumlah & 214,153 \\
\hline
\end{tabular}

Berdasarkan tabel diatas menunjukkan bahwa pada hasil angket prestasi belajar siswa SD Negeri Pannara Kota Makassar dengan nilai rata-rata 32,58. Nilai terendah yaitu 31,00 dan nilai tertinngi 39,00 dengan standar devition 2,255 .

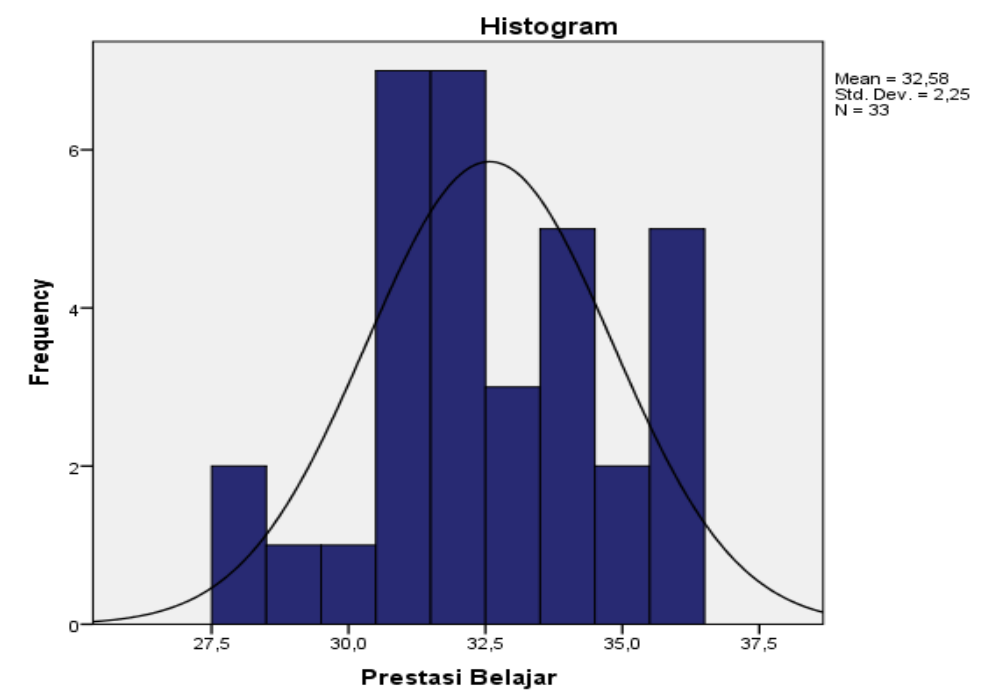

Berdasarkan data diatas maka diperoleh hasil angket prestasi belajar siswa SD Negeri Pannara Kota Makassar dengan nilai terendah 31,00 nilai tertinggi 39, 00 dan nilai rata-rata 32,58 dengan std devation 2,255.

\section{KESIMPULAN}

Berdasarkan hasil analisis data baik secara deskriptif maupun inferensial dalam pembahasan, hasil penelitian maka penulis dapat mengemukakan kesimpulan bahwa terdapat pengaruh pembelajaran daring terhadap prestasi belajar siswa SD Negeri Pannara Kota Makassar. Hasil tersebut dapat diketahui setelah pembagian angket atau kusioner kepada siswa. Siswa yang menjadi sampel dalam penelitian 
ini adalah siswa kelas VA SD Negeri Pannara Kota Makassar yang terdiri dari 33 siswa.

Hasil penelitaan ini menggunakan statistik deskriptif dengan nilai rata-rata pembelajaran daring 32,52 dan nilai prestasi belajar siswa 32, 58 sehingga dapat dikategorikan sangat baik. Analisis statistik inferensial, hasil coba normalitas pembelajaran daring 0,346 >0,05 (berdistribusi normal) dan prestasi belajar 0,078 $>0,05$ (berdistribusi normal) hasil uji homogenitas adalah 0,227 >0,05 (homogen), hasil uji leneritas adalah 0,092 > 0,05 dengan demikian terdapat linear pengaruh pembelajaran daring terhadap prestasi belajar siswa. Hasil uji hipotesis menunjukkan nilai Sig 0,000 dengan kriteria $\operatorname{Sig}(0,000)<\alpha(0,05)$ sehingga $\mathrm{H}_{0}$ ditolak dan $\mathrm{H}_{1}$ diterima.

\section{BIBLIOGRAFI}

Amaliyah Nurhadifa. 2020. Peningkatan Prestasi Belajar Siswa Dengan Model Pembelajaran Kooperatif Make A Amacth Pada Mata Pelajaran IPS Sekolah Dasar. Celebes education Review, 2.1: 66-71

Arifin, Zainal. 2014. Penelitian Pendidikan dan Paradigma Baru. Bandung: PT Remaja Rosdakarya

Achmad Chairidin. 2020. Pengaruh Pembelajaran Online terhadap Prestasi Siswa SD dan Ma,arif gendanga: Negeri Sala Tiga

Arikunto, 2010. Prosedur Penelitian Suatu Pendekatan Praktek. Jakarta Rineka Cipta

Bilfaqih, Yusuf. 2015. Esesnsi Pengembangan Pembelajaran Daring. Yogyakarta: Deepublish

Depdiknas.2006. Permendiknas No 22 Tahun 2006 Tentang Standar Isi. Jakarta.

Fathurrohman, Muhammad. 2017. Belajar dan Pembelajaran Modern Yokyakarta: PT Garudahawaca.

Isman. 2016. pembelajaran media Dalam Jaringan (modal jaringan). The Progresive And fun Education Seminar, 586.

Jusmawati, J., Satriawati, S., Akhiruddin, A., Rahman, A., Arsyad, N., \& Irman, R. (2021). Mengembangkan perangkat pembelajaran matematika berbasis model creative problem solving di sekolah dasar. Tinjauan Linguistik dan Budaya , 5 (1), 406-421.

K.Gilang.R. 2020.Pelaksanaan Pembelajarang Daring di Era Covid 19 Jawa Tengah:pancarundang Ajibarang. 
Martono, Nanang. 2012. Metode Penelitian Kuatitatif. Jakarta: PT Raja grafindo Persada.

Munir, 2009. Pembelajaran Jarak Jauh Berbasis Teknolog Informasi Dan Komonikasi. Bandung: Alfabeta

Pohan Efendi Albert, 2020. Kosep Pembelajaran Daring Berbasis Pendekatan Ilmia. Jawa Tengah: CV Sarnu Untung

Satriawati, dkk. 2018. Pengaruh Berafiliasi Terhadap Keaktifan Belajar Siswa SD Inpres Perumnas Antang Kota Makassar JRPD (Jurnal Riset Pendidikan Dasar ), 1(2) 158-165

Sugiyono, 2016. Metode Penelitian Kuantitatif Kualitatif dan $R \&$ D.Bandung Alfabeta.

Suswanto,Wiji. 2017. Dasar-Dasar IlmuPendidikan. Jakarta: Ar-Ruzz Media.

Suyono, Harianto. 2017. Belajar Dan Pembelajaran.Bandung: PT Remaja Rosdakarya Ofset

Syarifudin, 2020. Implementasi Pembelajaran Daring. Jakarta. Kencana.

Tatang S. 2012. Ilmu Pendidikan. Bandung: CV Pustaka Setia.

Thobrini,M. 2017.Belajar Dan Pembelajaran Teori Dan Praktik.Yokyakarta:PT. Ar-Ruzz Media

Thobroni, 2016. Belajar \& Pembelajaran Yokyakata Ar- Ruzz Media

Wahyono, Poncojari. 2020. Belajar dan Pembelajran di Era Milineal. Malang: PT.Universitas Muhammadyah

Yasa, D.2008. Aktivitas dan Prestasi Belajar. Jakarta : Depdikmas, Pendidikan Anak Usia Dini. Jakarta: PT. Karisma Putra Utama

Yatima, Dorotul. 2017. Landasan Pendidikan. Jakart : CV Alumgada Mandiri

Yulmitasari, 2020. Pengaruh Perhatian Orang Tua Terhadap Prestasi belajar Siswa SD Impres Borong Jammbu II Kota Makassar. Skiripsi: Universitas MegaRezky

Zaiful Rosyid, dkk. 2019. Prestasi Belajar. Malang: CV Literasai Nusantara Abadi.

Zulfitria, Z. (2018). Pengaruh Latar Belakang Pendidikan Orang Tua Terhadap Prestasi Belajar Siswa SD. Jurnal Holistika, 2(1). 
Jusmawati, J., Satriawati, S., Akhiruddin, A., Rahman, A., Arsyad, N., \& Irman, R. (2021). Developing mathematics learning devices based on creative problem solving model in elementary school. Linguistics and Culture Review, 5(1), 406-421. 